\title{
Nutritional Behavior of Heliconia Grown Under Different Levels of Lime
}

\author{
Gisele O. de Sousa ${ }^{1}$, Ismael de J. M. Viégas ${ }^{1}$, Jessivaldo R. Galvão ${ }^{1}$, Deivison R. da Silva ${ }^{1}$, Tiago K. M. Yakuwa ${ }^{1}$, \\ Vicente F. A. Silva ${ }^{1}$, Daniel P. Pinheiro ${ }^{1}$, Nilvan C. Melo ${ }^{2}$, Diocleia A. S. Silva ${ }^{1}$ \& Raykleison I. dos R. Moraes ${ }^{1}$ \\ ${ }^{1}$ Universidade Federal Rural da Amazônia, Belém, Pará, Brazil \\ ${ }^{2}$ Instituto Federal de Ciência e Tecnologia, Macapá, Amapá, Brazil \\ Correspondence: Jessivaldo R. Galvão, Institute of Agricultural Sciences, Soil Department, Universidade Federal \\ Rural da Amazônia, Tancredo Neves, No 2501, Montese, Belém, State of Pará, Brazil. Tel: 55-919-8842-1133. \\ E-mail: jessi.galvao50@gmail.com
}

Received: November 18, 2018

doi:10.5539/jas.v11n4p559
Accepted: January 3, $2019 \quad$ Online Published: March 15, 2019

URL: https://doi.org/10.5539/jas.v11n4p559

\begin{abstract}
Production and commercialization of tropical flowers and plants has grown in recent years, mainly due to the increasing value of these products in temperate climate countries, such as heliconia, one of the most cultivated tropical ornamental plants in Brazil. This study was developed to determine the effect of lime applications on the nutrients in heliconia plants (Heliconia psittacorum L. $\times$ Heliconia sparthocircinata Arist. [cv. Golden Torch]) cultivated in yellow latosol in a greenhouse. The macronutrient levels in the leaves, pseudostem and roots of the heliconia plants were determined after cultivating the plants in containers with a medium texture, yellow latosol, collected from the 0 to $20 \mathrm{~cm}$ layer and submitted to doses of $0,0.9,2.6,4.2$ and $5.9 \mathrm{t}$ of lime ha ${ }^{-1}$. Nitrogen and phosphorous performed better in the absence of the correction and in the $0.9 \mathrm{t} \mathrm{ha}^{-1}$ dose for the vegetative parts of the heliconia plants. The application of dolomitic lime promoted greater absorption of potassium, calcium and magnesium, and sulfur performed better for the doses 2.6 and $5.9 \mathrm{t}$ of lime $\mathrm{ha}^{-1}$, for the pseudostem and roots, respectively.
\end{abstract}

Keywords: Heliconia spathocircinata, limestone, mineral nutrition, tropical flower

\section{Introduction}

Heliconia psittacorum $\times H$. spathocircinata Aristeguieta is an herbaceous plant that forms clumps and has an underground rhizome. It has an erect, terminal inflorescence with four to eight orangish-yellow bracts and yellowish flowers. The intense and often very contrasting colors make this plant attractive to the consumer. It is often used in gardens and as a cut flower in floral arrangements and has a light inflorescence with bracts deposited in the same plane, allowing it to be stored and transported in boxes (Loges et al., 2005; Castro \& Gonçalves, 2007).

Heliconia is one of the most cultivated ornamental plants in the Northeast Region of Brazil, and Pernambuco, Alagoas and Ceará are the main exporting states (Aki \& Pedrosa, 2002; Junqueira \& Peetz, 2007). Among Heliconia cultivars, Golden Torch is notable for being productive and flowering throughout the year and is the most commercialized cultivar in the world (Castro \& Gonçalves, 2007). This cultivar tolerates acidic soils (a pH between 4.5 and 6.5 is adequate for cultivation) and nitrogen, phosphorous, potassium, magnesium, iron and manganese are the nutrients it demands the most (Lamas, 2004). Although fertilizing is one of the factors that most influences production, quality and resistance to diseases, studies about the effect of soil fertility are still scarce for this cultivar (Cerqueira et al., 2008; Castro et al., 2015).

Lime can be important because it increases the $\mathrm{pH}$, directly influencing the availability of nutrients, such as $\mathrm{K}$, $\mathrm{Ca}, \mathrm{Mg}, \mathrm{N}, \mathrm{S}$ and $\mathrm{P}$ that are less available when the $\mathrm{pH}$ is low. Thus, the objective of this study was to determine the effect of applying doses of dolomitic lime on macronutrient levels in heliconia plants (Heliconia psittacorum L. $\times$ Heliconia spathocircinata Arist., cv. Golden Torch) cultivated in a medium texture, yellow latosol, in the municipality of Belém, PA. 


\section{Material and Methods}

\subsection{Research Methodology}

The study was conducted in a greenhouse in the municipality of Belém, PA. The experiment was a completely randomized design with five treatments and five replicates. The heliconia plants (Heliconia psittacorum L. $\times$ Heliconia sparthocircinata Arist. [cv. Golden Torch]) were cultivated in $20 \mathrm{dm}^{3}$ plastic containers, which were the experimental units. There were five treatments: $0,0.9,2.6,4.2$ and $5.9 \mathrm{t}$ of lime ha ${ }^{-1}$, being the rate $0 \mathrm{t} \mathrm{ha}^{-1}$ the control treatment, and the rest aimed to increase the base saturation of the soil (V\%) to 20, 40, 60 and $80 \%$, espectively. The soil used in the experiment was a medium texture, yellow latosol. The chemical characteristics of lime were the following: $32 \% \mathrm{CaO}, 13 \% \mathrm{MgO}, 67 \% \mathrm{PN}$ and $85.16 \%$ PRNT.

\subsection{Soil Preparation}

First, the soil was incubated for 30 days with the lime, according to the treatments, in $20 \mathrm{dm}^{3}$ plastic containers. After incubation, heliconia rhizomes were planted which had a stem that was approximately $15 \mathrm{~cm}$. The plants were fertilized with an application of $150 \mathrm{mg}$ of $\mathrm{N} \mathrm{kg}^{-1}, 50 \mathrm{mg}$ of $\mathrm{P} \mathrm{kg}^{-1}, 125 \mathrm{mg}$ of K kg${ }^{-1}$ and $30 \mathrm{mg}$ of $\mathrm{NaSO}_{4}$ $\mathrm{kg}^{-1}$ at 30, 60 and 90 days after planting, in addition to an application of $0.5 \mathrm{mg}$ of $\mathrm{H}_{3} \mathrm{BO}_{3} \mathrm{~kg}^{-1}, 1.0 \mathrm{mg}$ of $\mathrm{CuSO}_{4}$ $\mathrm{kg}^{-1}, 2.0 \mathrm{mg}$ of $\mathrm{MnSO}_{4} \mathrm{~kg}^{-1}$ and $2.0 \mathrm{mg}$ of $\mathrm{ZnSO}_{4} \mathrm{~kg}^{-1}, 30$ and 60 days after planting. The containers were watered every two days and the saturation humidity was maintained at $60 \%$.

Two hundred and ten days after planting, the plants were collected and separated into different parts (leaves, pseudostem and roots), put in paper bags and placed in a forced air circulation dryer, maintained at $70{ }^{\circ} \mathrm{C}$, until a constant weight was reached. Subsequently, the dry material of each plant part was weighed. The material was then ground with a Willey mill ( $2 \mathrm{~mm}$ mesh sieve) and chemically analyzed to determine the $\mathrm{N}, \mathrm{P}, \mathrm{K}, \mathrm{Ca}, \mathrm{Mg}$ and $\mathrm{S}$ macronutrient concentrations in the dry mass of the leaves, pseudostem and roots. The macronutrients $\mathrm{N}, \mathrm{P}$, $\mathrm{K}, \mathrm{Ca}, \mathrm{Mg}$, and $\mathrm{S}$ were determined based on the procedure in Silva (2009). The results were subjected to an analysis of variance and, when significant, a regression analysis.

\section{Results and Discussion}

The nutrient levels in the heliconia plant parts were modified by lime applied to the soil (Table 1). The application of $0.9 \mathrm{t}$ lime ha ${ }^{-1}$ was responsible for the highest level of $\mathrm{N}$ in the leaves and pseudostem. For the roots, the highest level was obtained without applying lime and $\mathrm{N}$ levels decreased as the dose increased.

Table 1. N, P, K, Ca and Mg contents in leaves, pseudostem and roots in Heliconia psittacorum L. $\times$ Heliconia 66 spathocircinata Arist. cv. Golden Torch at 210 days of age, due to limestone doses

\begin{tabular}{|c|c|c|c|c|c|c|c|c|}
\hline \multirow{2}{*}{ Content } & \multirow{2}{*}{ Part Vegetative } & \multicolumn{5}{|c|}{ Doses in limestone $\left(\mathrm{t} \mathrm{ha}^{-1}\right)$} & \multirow{2}{*}{$\mathrm{MSE}^{1}$} & \multirow{2}{*}{ Regression equation } \\
\hline & & 0 & 0.9 & 2.6 & 4.2 & 5.9 & & \\
\hline \multirow{3}{*}{$\mathrm{N}\left(\mathrm{g} \mathrm{kg}^{-1}\right)$} & Leaves & 28.8 & 29.2 & 26.1 & 23.8 & 25.0 & 1.1 & $\hat{\mathrm{Y}}=29.580-1.772 \mathrm{x}+0.154 \mathrm{x}^{2}$ \\
\hline & Pseudostem & 17.0 & 18.6 & 16.7 & 16.1 & 15.0 & 1.1 & $\hat{Y}=17.534+0.136 x+0.097 x^{2}$ \\
\hline & Roots & 32.5 & 28.2 & 18.9 & 15.2 & 12.8 & 0.9 & $\hat{\mathrm{Y}}=33.044-7.079+0.699 \mathrm{x}^{2}$ \\
\hline \multirow{3}{*}{$\mathrm{P}\left(\mathrm{g} \mathrm{kg}^{-1}\right)$} & Leaves & 6.8 & 8.1 & 6.1 & 6.2 & 6.3 & 1.0 & $\hat{\mathrm{Y}}=7.355-0.363 \mathrm{x}+0.028 \mathrm{x}^{2}$ \\
\hline & Pseudostem & 4.7 & 2.6 & 3.6 & 4.3 & 3.9 & 0.6 & $\hat{Y}=4.002-0.426 x+0.079 x^{2}$ \\
\hline & Roots & 4.9 & 2.9 & 3.8 & 4.5 & 5.0 & 0.7 & $\hat{\mathrm{Y}}=4.328-0.672 \mathrm{x}+0.139 \mathrm{x}^{2}$ \\
\hline \multirow{2}{*}{$\mathrm{K}\left(\mathrm{g} \mathrm{kg}^{-1}\right)$} & Leaves & 8.9 & 10.8 & 9.6 & 10.1 & 10.9 & 0.9 & $\hat{\mathrm{Y}}=9.556-0.149 \mathrm{x}+0.007 \mathrm{x}^{2}$ \\
\hline & Roots & 6.1 & 7.2 & 7.2 & 8.9 & 8.6 & 0.4 & $\hat{\mathrm{Y}}=6.245+0.642 \mathrm{x}+0.031 \mathrm{x}^{2}$ \\
\hline \multirow{3}{*}{$\mathrm{Ca}\left(\mathrm{g} \mathrm{kg}^{-1}\right)$} & Leaves & 3.2 & 3.8 & 5.4 & 8.0 & 6.2 & 1.0 & $\hat{\mathrm{Y}}=2.809+1.656 \mathrm{x}+0.166 \mathrm{x}^{2}$ \\
\hline & Pseudostem & 3.0 & 3.9 & 5.2 & 6.6 & 6.6 & 0.3 & $\hat{Y}=2.969+1.128 x+0.082 x^{2}$ \\
\hline & Roots & 3.5 & 4.6 & 4.8 & 5.7 & 5.9 & 0.3 & $\hat{Y}=3.696+0.627 x+0.043 x^{2}$ \\
\hline \multirow{3}{*}{$\operatorname{Mg}\left(\mathrm{g} \mathrm{kg}^{-1}\right)$} & Leaves & 1.2 & 1.6 & 3.1 & 3.3 & 3.6 & 0.4 & $\hat{\mathrm{Y}}=1.106+0.884 \mathrm{x}+0.080 \mathrm{x}^{2}$ \\
\hline & Pseudostem & 1.6 & 3.8 & 5.8 & 8.6 & 8.5 & 0.8 & $\hat{Y}=1.709+2.175 x+0.168 x^{2}$ \\
\hline & Roots & 1.2 & 3.3 & 6.2 & 10.6 & 11.8 & 0.5 & $\hat{\mathrm{Y}}=1.201+2.263 \mathrm{x}+0.072 \mathrm{x}^{2}$ \\
\hline
\end{tabular}

Note. ${ }^{1}$ MSE: Mean Standard Error.

Bratti et al. (2012) evaluated the level of $\mathrm{N}$ in gladiolus leaves after applying lime, and showed that doses over $2.05 \mathrm{tha}^{-1}$ promoted the absorption of $\mathrm{N}$; they obtained a maximum level of $12.9 \mathrm{~g} \mathrm{~kg}^{-1}$ of $\mathrm{N}$ with a dose of $8 \mathrm{t}$ 
$\mathrm{ha}^{-1}$. According to these authors, lime facilitates the mineralization of nitrogen, making it easier for the plant to use the nutrient. In the present study, however, it was found that the $\mathrm{N}$ content in leaves, pseudostem and roots available to the heliconia plants were not influenced by the increase of lime applied.

The highest levels of $\mathrm{P}\left(8.1 \mathrm{~g} \mathrm{~kg}^{-1}\right)$ and $\mathrm{K}\left(10.8 \mathrm{~g} \mathrm{~kg}^{-1}\right)$ in the leaves were obtained with the application of $0.9 \mathrm{t}$ lime ha ${ }^{-1}$. The level of $\mathrm{P}$ in the pseudostem and roots was not statistically significant among the doses of $0,2.6$, 4.6 and $5.9 \mathrm{t} \mathrm{lime} \mathrm{ha}^{-1}$; the values of $\mathrm{P}$ for the lowest and highest dose being 4.7 and $3.9 \mathrm{~g} \mathrm{~kg}^{-1}$ in the pseudostem and 4.9 to $5.0 \mathrm{~g} \mathrm{~kg}^{-1}$ in the roots. The lowest levels of $\mathrm{P}$ in the pseudostem and roots $\left(2.6 \mathrm{~g} \mathrm{~kg}^{-1}\right.$ and $2.9 \mathrm{~g} \mathrm{~kg} \mathrm{~g}^{-1}$, respectively) were observed for the application of $0.9 \mathrm{tlime}_{\mathrm{ha}}{ }^{-1}$.

The $\mathrm{P}$ is fundamental in the export of carbon in the leaves (source) through the sinks during the reproductive period of the plant and the carbohydrates are used as energetic resource during that period (Pieters et al., 2001; Yee \& Tissue, 2005). According to Castro et al. (2015), P can directly influence the level of carbohydrates in the floral stem of heliconia.

The levels of $\mathrm{Ca}$ and $\mathrm{Mg}$ in the vegetative parts can be explained by the fact that the chemical composition of lime includes $32 \% \mathrm{CaO}$ and $13 \% \mathrm{MgO}$. The highest level of $\mathrm{Ca}$ in the leaves was observed for the application of $4.2 \mathrm{t}$ lime $\mathrm{ha}^{-1}$. For this dose of lime, elevated levels of $\mathrm{Ca}$ were also observed in the pseudostem and roots, which was not significantly different from that observed for $5.9 \mathrm{t}$ lime ha $\mathrm{a}^{-1}$. In the pseudostem and roots, the Ca levels for the doses 4.2 and $5.9 \mathrm{t} \mathrm{ha}^{-1}$ varied considerably. For the level of $\mathrm{Mg}$ in the leaves, there was a significant increase starting with the application of $2.6 \mathrm{t} \mathrm{lime} \mathrm{ha}^{-1}$ which did not highly change for other higher doses. In the pseudostem, the highest levels $\left(8.6\right.$ and $\left.8.5 \mathrm{~g} \mathrm{~kg}^{-1}\right)$ were obtained with the application of 4.2 and 5.9 $\mathrm{t}$ lime $\mathrm{ha}^{-1}$. In the roots, the highest levels of $\mathrm{Mg}$ were obtained when applying the highest dose of lime.

The levels of $\mathrm{K}$ in the heliconia plants, with the application of the dolomitic lime differ from the results of other studies of species of cut flowers (Bratti et al., 2012). According to Malavolta (2006), the antagonism between K and $\mathrm{Ca}$ is a result of competition in the soil solution. At low concentrations $\mathrm{Ca}$ can have a stimulating effect on the absorption of $\mathrm{K}$; however, increasing the $\mathrm{Ca}$ concentration decreases the stimulus until the interaction between these cations becomes antagonistic, causing a reduction in the absorption of K by the plants (Soares et al., 1983).

Applying lime increases the $\mathrm{pH}$, neutralizes aluminum, provides calcium and magnesium and promotes the development of the root system, improving efficiency in the use of nutrients and water in the soil (Faquin, 2005). This explains the higher levels of $\mathrm{Ca}$ and $\mathrm{Mg}$ with the increase in the dose of lime applied.

\section{Conclusions}

The application of dolomitic lime to medium textured, yellow latosol promotes changes in the nutrient levels in the leaves, pseudostem and roots of plants of Heliconia psittacorum L. $\times$ Heliconia sparthocircinata Arist. cv. Golden Torch.

\section{References}

Aki, A., \& Pedrosa, J. M. (2002). Aspectos da produção e consumo de flores e plantas ornamentais no Brasil. Revista Brasileira de Horticultura Ornamental, 8(1/2), 13-23. https://doi.org/10.14295/rbho.v8i1.304

Bratti, E. F., Rosa, Y. B. C. J., Silva, E. F., Rosa Júnior, E. J., Zárate, N. A. H., Bíscaro, G. A., \& Rosa, D. B. C. J. (2012). Cultivo de gladíolos em função das doses de calcário e potássio. Horticultura Brasileira, 30(3), 397-402. https://doi.org/10.1590/S0102-05362012000300007

Castro, A. C. R., Willadino, L. G., Loges, V., Castro, M. F. A. de., \& Aragão, F. A. S. de. (2015). Macronutrients deficiency in Heliconia psittacorum $\times$ Heliconia spathocircinata 'Golden Torch'. Revista Ciência Agronômica, 46(2), 258-265. https://doi.org/10.5935/1806-6690.20150005

Castro, C. E. F., \& Gonçalves, C. (2007). Produção e pós-colheita de flores e folhagens tropicais (p. 112). Fortaleza: Instituto Frutal.

Cerqueira, L. L., Fadigas, F. de S., Pereira, F. A., Gloaguen, T. V., \& Costa. J. A. (2008). Desenvolvimento de Heliconia psittacorum e Gladiolus hortulanus irrigados com águas residuárias tratadas. Revista Brasileira de Engenharia Agrícola e Ambiental, 12(6), 606-613. https://doi.org/10.1590/S1415-43662008000600006

Faquin, V. (2005). Nutrição mineral de plantas (p. 183). Lavras: UFLA/FAEPE.

Junqueira, A. H., \& Peetz, M. S. (2007). Las exportaciones brasileñas de flores y plantas ornamentales crescem más del 124\% entre 2001 y 2006. Horticultura Internacional, 1(56), 76-78.

Lamas, A. M. (2004). Floricultura Tropical: Tecnologia de cultivo (p. 65). Maceió: SEBRAE. 
Loges, V., Teixeira, M. do C. F., Castro, A. C. R. de., \& Costa, A. S. da. (2005). Colheita, pós-colheita e embalagem de flores tropicais em Pernambuco. Horticultura Brasileira, 23(3), 699-672. https://doi.org/ 10.1590/S0102-05362005000300001

Malavolta, E. (2006). Manual de nutrição mineral de plantas (p. 638). São Paulo: Editora Agronômica Ceres.

Mengel, K., \& Kirkby, E. A. (1978). Principles of plant nutrition (p. 593). Berna: International Potash Institute.

Pieters, A. J., Paul, M. J., \& Lawlor, D. W. (2001). Low sink demand limits photosynthesis under Pi deficiency. Journal of Experimental Botany, 52(358), 1083-1091. https://doi.org/10.1093/jexbot/52.358.1083

Silva, F. C. (2009). Manual de análises químicas de solos, plantas e fertilizantes (p. 627). Brasília: Embrapa Informação Tecnológica.

Soares, E., Lima, L. A., Mischan, M. M., Mello, F. A. F., \& Boaretto, A. E. (1983). Efeito da relação entre teores trocáveis de $\mathrm{Ca}$ e $\mathrm{Mg}$ do solo na absorção de $\mathrm{K}$ por plantas de centeio. Revista de Agricultura, 58(4), 315-330.

Yee, D., \& Tissue, D. T. (2005). Relationships between non structural carbohydrate concentration and flowering in a subtropical herb, Heliconia caribaea (Heliconiaceae). Caribbean Journal of Science, 41(1), $243-249$.

\section{Copyrights}

Copyright for this article is retained by the author(s), with first publication rights granted to the journal.

This is an open-access article distributed under the terms and conditions of the Creative Commons Attribution license (http://creativecommons.org/licenses/by/4.0/). 